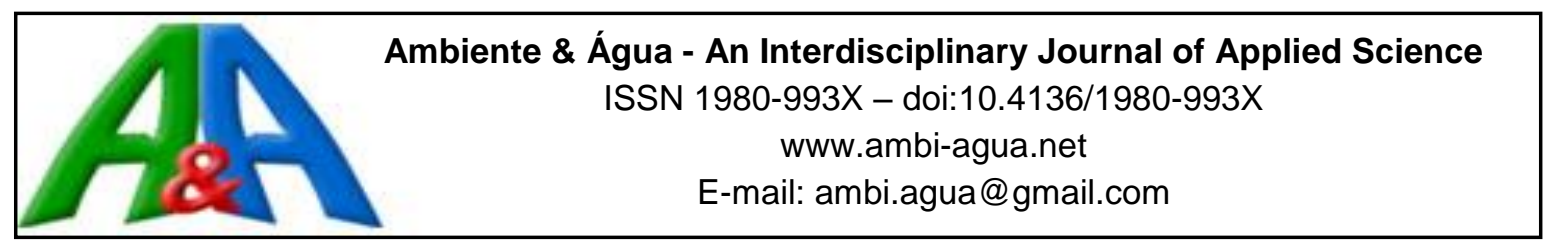

\title{
Social and environmental innovations of Brazilian companies
}

\author{
ARTICLES doi:10.4136/ambi-agua.2145
}

Received: 07 Jun. 2017; Accepted: 06 Feb. 2018

\section{Celso Machado Junior ${ }^{1 *}$; Maria Tereza Saraiva de Souza² ${ }^{2}$ Roberto Bazanini ${ }^{3}$; Daielly Melina Nassif Mantovani ${ }^{4}$; Cristiane Jaciara Furlaneto ${ }^{5}$}

\author{
${ }^{1}$ Faculdades Metropolitanas Unidas (FMU), São Paulo, SP, Brasil \\ Mestrado Profissional em Administração em Governança Corporativa (MPAGC) \\ E-mail: celsomachado1@ gmail.com \\ ${ }^{2}$ Fundação Educacional Inaciana Pe. Sabóia de Medeiros (FEI), São Bernardo do Campo, SP, Brasil \\ Programa de Mestrado e Doutorado em Administração (PMDA). E-mail: mariaterezasaraivas@gmail.com \\ ${ }^{3}$ Universidade Paulista (UNIP), São Paulo, SP, Brasil \\ Programa de Mestrado em Administração. E-mail: roberto.bazanini@terra.com.br \\ ${ }^{4}$ Faculdades Metropolitanas Unidas (FMU), São Paulo, SP, Brasil \\ Programa de Pós-Graduação em Administração (PPGA). E-mail: daimantovani@gmail.com \\ ${ }^{5}$ Universidade Paulista (UNIP), São Paulo, SP, Brasil \\ Conselho Superior de Ensino, Pesquisa e Extensão. E-mail: crisjaciara@gmail.com \\ *Corresponding author
}

\begin{abstract}
This paper focuses on the social and environmental innovations of Brazilian companies, rather than on merely economic innovations. These innovations are discussed within the context of sustainability. Data were collected via a qualitative and descriptive study from the annual Guia Exame de Sustentabilidade magazine (2014 Edition). The magazine stated that 228 companies responded to the questionnaire. Of these, 61 companies stood out in Brazil for their policies and practices in sustainability and had their results published. The social innovations were geared towards meeting the needs of the surrounding communities. Environmental innovations appeared in greater numbers, connoting a higher stage of attention and interest from Brazilian companies. Environmental innovations were intended to evolve or improve processes and products and to reduce the consumption of resources.
\end{abstract}

Keywords: efficient processes, reduction of greenhouse gases, socio-technical context.

\section{Inovações sociais e ambientais das empresas brasileiras}

\section{RESUMO}

Neste artigo, se investiga as inovações voltadas para aspectos sociais e ambientais, ao invés da análise de aspectos meramente econômicos, proporcionando assim o contexto da sustentabilidade. Este propósito é estabelecido para identificar as inovações sociais e ambientais desenvolvidas pelas empresas brasileiras. Os dados foram coletados através de um estudo qualitativo e descritivo da revista anual Guia Exame de Sustentabilidade (edição de 2014). A publicação de 2014 da revista identificou que 228 empresas responderam ao questionário. Destas, 61 empresas se destacaram no Brasil por suas políticas e práticas de sustentabilidade e publicaram seus resultados. As inovações sociais foram voltadas para atender às necessidades das comunidades vizinhas. As inovações ambientais apareceram em maior 
número, em estágio mais elevado de atenção e interesse em relação as sociais pelas empresas brasileiras. As inovações ambientais foram destinadas a desenvolver ou melhorar processos e produtos, bem como para a redução do consumo de recursos.

Palavras-chave: contexto sócio técnico, processos eficientes, redução de gases de efeito estufa.

\section{INTRODUCTION}

Social and environmental innovations, rather than merely economic innovations, are of interest to society. This research identifies Brazilian companies' social and environmental innovations through an investigation of 61 companies that disclosed details of their performance in the magazine Guia Exame de Sustentabilidade (2014).

The theory of economic development proposed by Schumpeter (1997) explains the elements that support the evolution of markets, countries and companies. According to this author, innovation has a close relationship with the establishment of new markets and the emergence of entrepreneurs. It is important that a government support research and development for its country's economic growth. In this way, Dosi (2006) argues that the growth and competitiveness of an industrial society can be encouraged by carrying out scientific and technological research, confirming Schumpeter's approach.

Through the Oslo Manual, the Organization for Economic Co-operation and Development (OECD, 2005) classifies innovation into four areas: product, process, marketing and organization. This division positions an innovation in the area from which it originated or in the area that had greater participation in it.

The Oslo Manual (OECD, 2005) is an international benchmark to measure innovation. Despite the greater attention paid to innovation in the industrial sector, the Oslo Manual enables the interpretation of innovation in various spheres of society. However, it focuses primarily on economic development, moving away from social and environmental issues, which, together with the economic variable, lay the foundations of sustainability.

In the context of economic innovation, Schumpeter (1997) argues that this can be achieved by producing new things, producing the same things in a new way (in various combinations of materials and forces) and making new combinations that bring financial returns.

The innovations that occur within the companies are thus important for the whole of society and influence the development of the country. Thus, this research identifies innovations of Brazilian companies that had social and environmental impact.

Design innovation based solely on financial returns is far from a sustainable development proposal. Concern for sustainability is a reality in most companies, whose management teams focus not only on economic aspects but also social and environmental aspects. The engagement of enterprises in the context of sustainability involves the need to change practices to address sustainable development. Barbieri et al. (2010) point out that in the process of innovation, organizations should incorporate the mitigation of social and environmental aspects. In this sense, besides benefiting the economy, innovation should contemplate society and the environment, consolidating the concept of sustainable development.

Authors like Bhatt and Altinay (2013) and Maclean et al. (2013) indicate that research on social innovation is in the embryonic stage, lacking theoretical and empirical studies. To Cajaiba-Santana (2014), social innovation studies are fractionated and diluted among various fields of knowledge. Bignetti (2011) identifies that research on social innovation is rare and rudimentary. The research field is still emerging. Bouchard (2012) proposes that social innovations aimed at social change present a new vision - a new way to evaluate and define problems and possible solutions. 
While sustainable development is a scientific field still developing, there are important studies with the potential to direct relevant research on this topic. Within the existing body of research, this study highlights contributions that support the discussion to be developed with the collected data. It is worth noting that the definition of social innovation is viewed as an innovative resolution that is designed to meet human needs (Mulgan, 2006) and to help to solve the social and environmental problems that afflict humanity (Maurer and Silva, 2014).

The innovation can be incremental that stems from improving or complementing something that already exists in the market, or radical that occurs abruptly implanting novelties in the market and discontinued what was in force. Foster and Heeks (2013) highlights the importance of the diffusion of new technologies in the economy and points out that such diffusion has four dimensions: management or technological trajectory; rhythm or rate of diffusion; conditions; and economic, social and environmental factors.

According to Chambon et al. (1982), social innovations are dynamics that allow an individual or a group of individuals to meet social demands or sets of social needs that are currently not met satisfactorily. Also, according to the authors, social innovation gives individuals a better condition than at present, characterizing a degree of novelty. For the authors, social innovation has four dimensions: (i) form - it is immaterial, represented by actions and practices; (ii) process - it requires involvement and commitment from conception to implementation; (iii) actors - consider people and their interaction with the environment; and (iv) change objectives - it solves social problems, allowing the unfolding of everyday life.

For Kanter (1999), social problems are also economic problems. The author points out the existence of companies that identify a favorable environment for social innovation and migrate corporate social responsibility to corporate social innovation. Thus, the author proposes that the commitment of companies to change involves the whole of society but differently than philanthropy; it identifies opportunities for learning and business development via research and development (R\&D). According to the author, social innovation seeks to solve the problems that affect society, such as those related to health, education and economic development.

The study of Holmes and Smart (2009) reviews open innovation in the context of corporate social responsibility, which approximates social innovation and social entrepreneurship. The authors also highlight the importance of businesses expanding their borders as a phenomenon that strengthens the process of innovation and social legitimacy.

The existence of links among diversity management, the process of innovation and superior performance in companies with greater attention to social aspects was observed in research conducted by Bridgstock et al. (2010). The authors position social innovation as the convergence of cultural aspects, in which the emphasis is on the importance of ideas and the understanding that social conditions could be different and better. Thus, social innovation meets currently unmet human and social needs, differing from business innovation that worries only about the consumer and the market. Attention to people and communities, not commercial gain, is what characterizes social innovation, according to Dawson and Daniel (2010). It is distinguished by developing concepts, strategies and tools to support social aspects in the improvement process. For these authors, social innovation is developed collaboratively in order to tackle social problems and relies on the generation and implementation of ideas undertaken collectively.

The aforementioned theoretical context establishes the first hypothesis of this research:

H1 - Social innovations made by companies are aimed at solving social problems.

Within the context of sustainability is also a concern for the environment. The environmental approach considers aspects related to energy consumption, reduction in the consumption of natural resources, and in the generation of pollution. Thus, new products and processes must contemplate innovative solutions that are not restricted to benefits for users, but 
also for the environment. Concern about environmental innovation comes from various segments of society. In the academic context, the journal Environmental Innovation and Societal Transitions (EIST) is exclusively dedicated to environmental innovation. In addition, magazines such as the Journal of Cleaner Production, the Journal of Industrial Ecology, Ecological Economics, Revista de Gestão Social e Ambiental and Revista Metropolitana de Sustentabilidade deal with issues related to environmental sustainability. Magazines such as Policy Research, Technological Forecasting and Social Change and the Journal of Evolutionary Economics deal with innovation. The areas of sustainability and innovation also manifest in the dissemination of research regarding environmental innovation.

Kemp and Pearson (2007) present environmental innovation as a concern surrounding the entire product lifecycle or service. For the authors, environmental innovation includes a new product, production process, service, management type or business model for the organization, causing a reduction in environmental risk, pollution and other possible negative impacts resulting from the use of resources in comparison with relevant alternatives.

Rennings (2000) defines environmental innovation or eco-innovation as innovation that contributes to sustainable development. Thus, in the industrial context, the development and use of environmental innovations have the potential to be mechanisms to achieve sustainability. Coenen and Díaz Lópes (2010) propose that environmental and social innovations undertaken responsibly provide technological, institutional and organizational shifts, which modify the basis of knowledge of production systems. Thus, to Van den Bergh et al. (2011), in industry, the significant transition towards sustainability is based on new forms of environmental innovation. Incremental improvements that seek to increase the environmental efficiency of existing production technologies and systems are not sufficient to achieve the demanded radical changes to establish sustainable development. However, the authors believe that environmental innovation is now incremental.

Environmental innovation designed to provide sustainable development in the industrial sector incorporates a systemic approach (Coenen and Díaz Lópes, 2010) involving sociotechnical systems that cover manufacturing, consumption and distribution. For Jacobsson and Bergek (2011) and Markard et al. (2012), environmental innovations contribute to sustainability, which in turn is positioned as an important large-scale transformation inductor, involving users, institutions, technological advances, the economy, political structures and other aspects. Markard et al. (2012) emphasize that research into socio-technical systems (such as power supply, water supply and urban transport) enhances the understanding of how different green technologies, competing with each other, enable the creation of new products, services, business models and organizations. In this regard, environmental innovation is established as an important component of sustainability and differentiation in the market.

As noted, the benefits resulting from environmental innovation are significant. However, studies identify the importance of considering the costs involved in the implementation of environmental improvements. Jorgenson et al. (2009) emphasize that the development of innovations involves long periods of research and costly investments. Their analysis indicates that the reduction of pollutant emissions in the coming decades will be more related to environmental regulation than to the intention of developing new products or services. In this conception, environmental innovation is a response of companies to meet legislation, not a natural vocation of the companies. Van den Bergh et al. (2011) emphasize that environmental innovations are geared towards meeting the pressing problems of society, which, however, are associated with external costs and do not enter the calculation of the direct cost to the polluter, for example, air pollution and solid waste disposal. If an industrial agent (a polluter) is not encouraged to invest in environmental innovations or new environmentally friendly technologies, it will affect its internal costs. In this context, the existence of laws is an important 
incentive for environmental innovation, as it includes variable social costs that are borne by society in general.

Van den Bergh et al. (2011) also point out that several empirical studies on environmental innovation have focused on variable costs. In this sense, cost (present and future projections) materializes as an important factor affecting both producers and consumers, who are more sensitive to initial costs than long-term costs.

From this context emanates the second hypothesis of this research:

H2 - Environmental innovations are geared towards meeting the demands of the sociotechnical system.

Combined with innovation focused on economic growth, social and environmental innovations are important variables for sustainable development. Thus, the innovation process must consider all the variables involved in order to ensure the sustainable development of society and that the demands of society are met in full.

\section{METHODOLOGY}

This study, according to its general purpose, can be characterized as qualitative and descriptive, using secondary data. Data were collected from the annual magazine Guia Exame de Sustentabilidade (2014 edition), published by Editora Abril publishing company. The first edition was published in 2000, and the magazine follows a methodology developed by the Center for Sustainability of the Fundação Getúlio Vargas (Guia Exame de Sustentabilidade, 2014). The publication has focused attention on the process of establishing a ranking of companies that declare that their management teams focus attention on sustainability. The 2014 magazine stated that 228 companies responded to the questionnaire. Of these, 61 companies stood out in Brazil for their policies and practices in sustainability and had their results published.

In addition to the indicators presented, the 2014 magazine allowed companies to describe three recently deployed sustainability reports, which described the benefits and results in $2013 / 2014$ and those that were incomplete. The reports could discuss projects, programs, initiatives and practices related to sustainability. Each company was able to offer three accounts of sustainability along the following themes: governance and sustainability, human rights, community relations, supplier management, water management, biodiversity management, waste management, climate change (including management energy), relationships with customers/consumers, and transparency and fighting corruption. If a company wished, it could be exempted from presenting a sustainability report.

This study develops content analysis that, through pre-analysis, in line with the work of Bardin (2009), makes it possible to establish the categorization and codification of the reports submitted by the companies. This process seeks to identify social and environmental innovations. All reports presented in the 2014 Guia Exame de Sustentabilidade are referenced in a new list and classified into two categories, namely, social innovation and environmental innovation. The search for a framework for reports based on environmental and social innovation is justified both by the reporting approach of reports that should portray recent activities and incomplete activities, and the demand for companies to present new solutions that meet the paradigms of sustainability. Table 1 presents the concepts used to frame the reports submitted by the companies. Note that these concepts were presented in the theoretical chapter. 
Table 1. Concepts used to classify sustainability reports.

\begin{tabular}{ll}
\hline Category & Concept \\
\hline Social Innovation & Proposals aimed at social change present a new vision - a new way to evaluate \\
& and define problems and possible solutions (Bouchard, 2012). \\
& Social innovations are dynamics that allow an individual or a group of \\
& individuals to meet social demands or sets of social needs that are currently not \\
& met satisfactorily (Chambon et al., 1982). \\
& Social innovation is the convergence of cultural aspects, in which the emphasis \\
& is on the importance of ideas and the understanding that social conditions could \\
& be different and better (Bridgstock et al., 2010). \\
\hline Environmental Innovation & Environmental innovation includes a new product, production process, service, \\
& management type or business model for the organization, causing a reduction \\
& in environmental risk, pollution and other possible negative impacts of \\
& resource use in comparison with relevant alternatives (Kemp and Pearson, \\
& 2007). \\
& Environmental innovation is designed to provide sustainable development in \\
the industrial sector and incorporates a systemic approach (Coenen and Díaz & Lópes, 2010). \\
Environmental innovations contribute to sustainability, which in turn is \\
positioned as an important large-scale transformation inductor, involving users, \\
institutions, technological advances, the economy, political structures and \\
other aspects (Jacobsson and Bergek, 2011; Markard et al. 2012). \\
In environmental innovation, cost (present and future projections) materializes \\
as an important behavioral factor of producers and consumers, who are more \\
sensitive to initial costs than long-term costs (Van den Bergh et al., 2011). \\
\hline
\end{tabular}

Source: Prepared by the authors, based on the references cited.

The next chapter presents the data observed in the content analysis through the classifications of environmental innovation and social innovation.

\section{PRESENTATION AND ANALYSIS OF DATA}

The synthesis of the collected data is presented in Table 2. All the data obtained can be seen in Appendix A, presented at the end of this article, with the classification of the reports of companies into environmental innovation (EI) or social innovation (SI).

The data show 49 environmental innovations and 22 social innovations, and it was established that 11 companies had both environmental and social innovations. Bradesco was the only company not to present environmental or social innovations. The innovations highlighted by the company related to the technological field, with the potential to result in environmental and social benefits; however, the account of the company did not make this relationship clear. Figure 1 shows the distribution of companies with environmental and/or social innovations.

The data present four groups of companies. The first group presents only environmental innovations with 38 companies (62.3\%); the second group with 11 companies (18\%) present both environmental and social innovations; the third group with 11 companies (18\%) present only social innovations; and the last group with a company that presents an innovation that does not fit as environmental or social. Thus, in the aggregate of the companies of the first group with those of the second group, a total of 49 companies (80.3\%) are identified investing in environmental innovations, showing that this practice is of most interest to companies. 
Table 2. Synthesis of reports highlighted by companies, from Appendix A.

\begin{tabular}{|c|c|c|c|c|c|}
\hline Sector & $\begin{array}{l}\text { Number } \\
\text { of firms }\end{array}$ & $\begin{array}{c}\text { Number of } \\
\text { innovations } \\
\text { introduced }\end{array}$ & $\begin{array}{c}\% \text { of } \\
\text { innovation } \\
\text { in the } \\
\text { sample }\end{array}$ & $\begin{array}{l}\text { Number of } \\
\text { environmental } \\
\text { innovation } \\
\text { introduced }\end{array}$ & $\begin{array}{l}\text { Number of } \\
\text { Social } \\
\text { Innovation } \\
\text { introduced }\end{array}$ \\
\hline Agribusiness & 3 & 3 & $4.22 \%$ & 2 & 1 \\
\hline Auto Industry & 2 & 2 & $2,82 \%$ & 2 & 0 \\
\hline Capital Goods & 2 & 2 & $2,82 \%$ & 2 & 0 \\
\hline Consumer Goods & 6 & $7 *$ & $9,86 \%$ & 5 & 2 \\
\hline Construction & 1 & 2 & $2,82 \%$ & 1 & 1 \\
\hline $\begin{array}{l}\text { Consulting and IT } \\
\text { Management }\end{array}$ & 3 & $4^{*}$ & $5,63 \%$ & 3 & 1 \\
\hline Electronics & 5 & $6^{*}$ & $8,45 \%$ & 5 & 1 \\
\hline Energy & 8 & $9^{*}$ & $12,68 \%$ & 7 & 2 \\
\hline Hotels & 1 & 1 & $1,41 \%$ & 1 & 0 \\
\hline Infrastructure & 2 & 2 & $2,82 \%$ & 1 & 1 \\
\hline $\begin{array}{l}\text { Financial } \\
\text { Institutions }\end{array}$ & 4 & $3 * *$ & $4.22 \%$ & 1 & 2 \\
\hline $\begin{array}{l}\text { Construction } \\
\text { Materials }\end{array}$ & 2 & $3 *$ & $4.22 \%$ & 2 & 1 \\
\hline $\begin{array}{l}\text { Mining and Steel } \\
\text { Mills }\end{array}$ & 7 & $9 *$ & $12,68 \%$ & 7 & 2 \\
\hline Paper and Cellulose & 2 & $3 *$ & $4.22 \%$ & 2 & 1 \\
\hline Chemistry & 5 & 5 & $7,05 \%$ & 4 & 1 \\
\hline Health Services & 4 & 4 & $5,63 \%$ & 1 & 3 \\
\hline Telecommunications & 2 & $3^{*}$ & $4.22 \%$ & 1 & 2 \\
\hline $\begin{array}{l}\text { Transportation and } \\
\text { Logistics }\end{array}$ & 1 & 1 & $1,41 \%$ & 1 & 0 \\
\hline $\begin{array}{l}\text { Small and medium } \\
\text { enterprises. }\end{array}$ & 1 & $2 *$ & $2,82 \%$ & 1 & 1 \\
\hline Total & 61 & 71 & $100 \%$ & 49 & 22 \\
\hline
\end{tabular}

Source: Prepared by the authors, based on the references cited.

Note: * there are institutions that present more than one innovation, ** One of the institutions presented innovation, but it does not fit as either environmental or social.

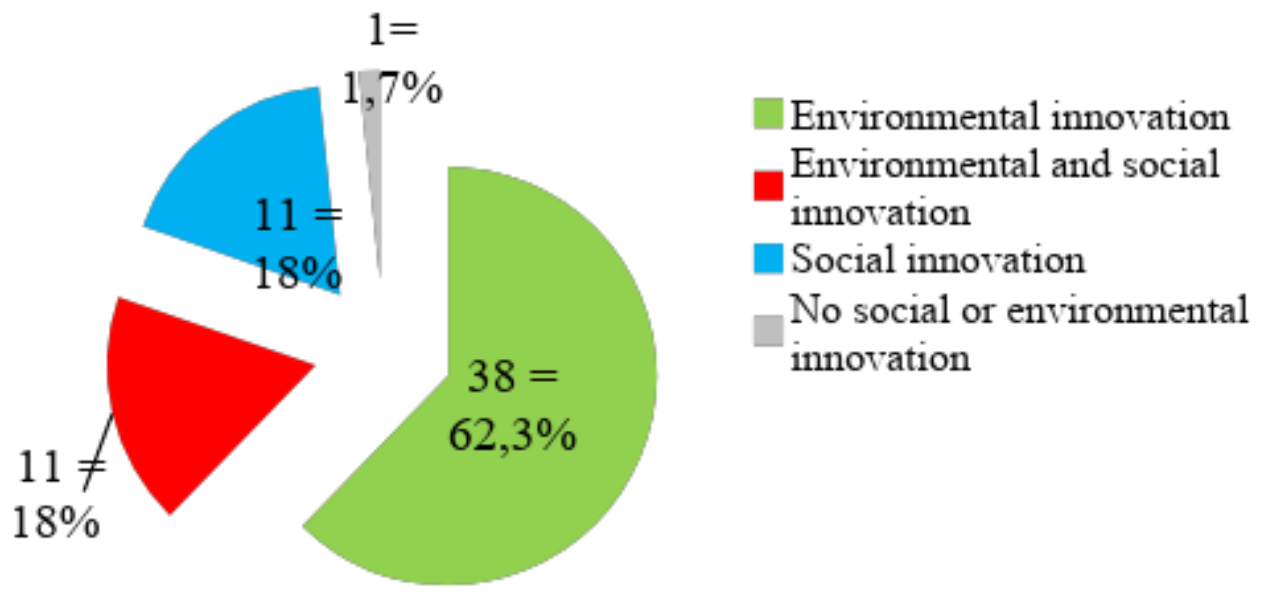

Figure 1. Distribution of companies with environmental and/or social innovations. Source: research data. 
Table 3 indicates the benefit themes of the social innovations of the companies. Social innovations present unique benefits. The social actions developed by the companies result in more social benefits than those listed; however, for the purposes of this research, the data are restricted to those reported by the companies. The relation of social innovations and their respective benefits can be seen in the Appendix A.

Supporting the community with nine occurrences (41\%) was established as a major focus of the companies that carried out social innovations. Next was enhancing professional capacity: in two situations, the target audiences were outside the companies, and in one situation it was the employees themselves. Next were establishing partnerships with collectors and mitigating the effects of the activities of the companies. With just one occurrence each were working with local suppliers, providing education for transit, providing financial education, fighting corruption, ensuring gender equality and improving digital inclusion.

Table 3. Benefit themes of the social innovations.

\begin{tabular}{lcclcc}
\hline Theme & Quantity & $\%$ & Theme & Quantity & $\%$ \\
\hline Support the community & 9 & 41,0 & Education for transit & 1 & 4,5 \\
Enhance professional capacity & 3 & 13,6 & Financial education & 1 & 4,5 \\
Partnerships with collectors & 2 & 9,2 & Fighting corruption & 1 & 4,5 \\
Mitigate the effects of activities & 2 & 9,2 & Gender equality & 1 & 4,5 \\
Local suppliers & 1 & 4,5 & Digital inclusion & 1 & 4,5 \\
\hline
\end{tabular}

Source: research data.

Table 4 shows the benefit themes of the environmental innovations of the companies. Note that environmental innovations can address various topics related to the environment; thus, Table 4 expresses all the benefits from the changes reported by the companies. Thus, an innovation can generate more than one benefit. It is worth mentioning that a total of 100 benefits were identified because of environmental innovations. The relationship of environmental innovations and their respective benefits can be observed in the Appendix A.

Table 4. Benefit themes of the environmental innovations.

\begin{tabular}{|c|c|c|c|c|c|}
\hline Theme & Quantity & $\%$ & Theme & Quantity & $\%$ \\
\hline Efficiency & 20 & 20 & Mitigate environmental impacts & 4 & 4 \\
\hline Electricity & 20 & 20 & Environmental certification & 3 & 3 \\
\hline Water & 10 & 10 & Environmental education & 2 & 2 \\
\hline Reuse/recycling & 8 & 8 & Good habits & 1 & 1 \\
\hline Reduction of GGEs & 7 & 7 & Carbon credit & 1 & 1 \\
\hline Supply chains / suppliers & 6 & 6 & Biotechnology - genetic improvemen & 1 & 1 \\
\hline Waste reduction & 6 & 6 & Risk assessment & 1 & 1 \\
\hline Reduction in resource consumption & 5 & 5 & Forest recovery & 1 & 1 \\
\hline New products & 4 & 4 & & & \\
\hline
\end{tabular}

Source: research data.

The data show greater attention paid to the search for efficiency and electricity management. The quest for efficiency in most cases was related to improvements that resulted in a lower consumption of natural resources and lower impacts of the byproducts and processes involved. Electricity was positioned as one of the resources that receives most attention from companies, followed by water. Reuse/recycling was in fourth position, which involves repurposing the leftovers or waste produced by the activities of the companies. The reduction of GGEs had seven occurrences. With six occurrences were improving supply chains / suppliers and ensuring waste reduction. The reduction in resource consumption had five occurrences, and new products had four occurrences. Environmental certification had three occurrences, while 
environmental education had two. With one occurrence each were good habits, carbon credit, biotechnology - genetic improvement, risk assessment and recovery of forests.

The following chapter discusses the survey data using the theoretical framework developed to support the research.

\section{DISCUSSION}

The data relating to social innovation indicate that it receives less attention from these companies than environmental innovation does. The data confirm the embryonic position of social innovation, as pointed out by Bhatt and Altinay (2013) and Maclean et al. (2013). In this sense, not only is social innovation research embryonic but the innovation process is also geared towards social change.

Supporting the community with nine occurrences represented $41 \%$ of the social innovations and was thus positioned as the subject of a greater volume of innovations. This theme incorporates, in most cases, actions that occur in the surroundings of companies and that aim to improve the social conditions of people nearby. This position matches the approach of Chambon et al. (1982), in which social innovation is intended to meet social needs that are not yet answered satisfactorily, or, as Mulgan (2006) proposes, is intended to meet human needs.

Enhancing professional capacity and creating partnerships with collectors have moredirect relationships with the need to provide people with their own conditions of subsistence. In this sense, social innovations are also configured as economic innovations, as proposed by Kanter (1999). In this case, the author indicates that social innovations offer opportunities for learning and business development, moving away from philanthropy. Actions to mitigate the effects of the company's activities are intended to prevent possible future problems; however, they are also a form of social innovation, based on the understanding that social conditions could be better and different, as proposed by Bridgstock et al. (2010).

Other matters dealt with by the companies' social innovations were quite diluted and addressed the following topics: local suppliers, education for transit, financial education, fighting corruption, gender equality and digital inclusion. This diversity of themes converges with the approach of Cajaiba-Santana (2014), who indicates that social innovation studies are diluted across different areas. Thus, the great diversity of social innovation studies is probably due to the multiplicity of subject matters of social innovation.

The accounts of social innovations developed by the companies did not point to obtaining commercial profit from these - a condition that adheres to the proposal of Dawson and Daniel (2010), for whom social innovation is developed collaboratively in order to solve social problems. This context confirms the first hypothesis established by this research.

The environmental innovations identified by the companies were geared towards efficiency, electricity, water, reuse/recycling, supply chains/suppliers, reduced consumption of resources, new products, mitigating environmental impacts, environmental education, biotechnology and the recovery of forests. These are types of sustainable development, according to the definition provided by Rennings (2000). This context confirms the proposition of Van den Bergh et al. (2011), that industry relies on innovation to achieve environmental sustainability.

The data show three companies, indicating their implementation of environmental certification processes. This was probably related to legal requirements, mainly due to wood exports. This mirrors the approach of Jorgenson et al. (2009), which highlights the influence of environmental regulations as a stimulating factor.

It was possible to identify a set of 20 innovations aimed at electricity consumption, matching the data of Van den Bergh et al. (2011), which highlights the concerns of producers and consumers with cost in the current context and in the future. Markard et al. (2012) found 
that environmental research is focused on socio-technical systems, which focus on electricity, water and urban transport. This research found that the organizations identified energy and water as company management elements, but urban transport was not identified. For Coenen and Díaz Lópes (2010) environmental innovations fall within the socio-technical context but they expand to a larger universe, which incorporates manufacturing, distribution and consumption. Thus, this research identified the main forms of environmental innovation as relating to efficiency, the consumption of electricity and water, reuse/recycling, the reduction of GGEs, supply chains / suppliers, waste reduction and reducing resource consumption. All of these actions relate to manufacturing, consumption and distribution. The results obtained confirmed the second hypothesis.

\section{CONCLUSION}

This paper proposed to identify Brazilian companies' social and environmental innovations. The developed research enabled us to identify several actions of social and environmental innovations practiced by Brazilian companies. Because the data used in this study were made available in a trade magazine accessible to any interested party, it can be inferred that the Brazilian companies disclosed their social and environmental innovations with this in mind.

Social innovations were presented in a smaller volume and were largely geared towards meeting the needs of surrounding communities. Social innovation actions also related to learning and business development, a condition that is far from a philanthropic approach.

Environmental innovations appeared in greater numbers than social innovations did, connoting a higher stage of attention and interest from Brazilian companies. Environmental innovations fall within the socio-technical context, with measures to develop or improve processes and/or resources. Among the topics of interest of the identified environmental innovations were searches for efficiency, reduced consumption of energy and water, reuse/recycling, the reduction of GGEs, supply chains / suppliers, reducing waste and reducing the consumption of resources.

One limitation of this study was the retrieval of data from a single publication. However, this limitation was due to the scarcity of publications dedicated to the area of sustainable innovation. This context limited the search for other sources of data.

This study reflects the current stage of social and environmental innovation of companies. However, because it is a topic of growing interest to companies, this study establishes the merit for further research to replicate this study in order to identify the progress and expansion of the interest in the subject. It is worth noting that a possible Brazilian economic contraction and increased disputes between businesses could result in reduced interest of companies in the issue, but there remains a need for studies to identify the variations that occur and the possible causative agents behind these changes.

\section{REFERENCES}

BARBIERI, J. C.; VASCONCELOS, I. F. G. de; ANDREASSI, T.; VASCONCELOS, F. C. de. Inovação e sustentabilidade: novos modelos e proposições. Revista de Administração de Empresas RAE, v. 50, n. 2, p. 146-154, 2010.

BARDIN, L. Análise de conteúdo. 5. ed. Lisboa: Edições 70, 2009.

BHATT, P.; ALTINAY, L. How social capital is leveraged in social innovations under resource constraints. Management Decision, v. 51, n. 9, p. 1772-1792, 2013. https://doi.org/10.1108/MD-01-2013-0041 
BIGNETTI, L. P. As inovações sociais: uma incursão por ideias, tendências e focos de pesquisa. Ciências Sociais Unisinos, v. 47, n. 1, p. 3-14, 2011. 10.4013/csu.2011.47.1.01

BOUCHARD, M. J. Social innovation, an analytical grid for understanding the social economy: the example of the Quebec housing sector. Service Business, v. 6, n. 1, p. 47-59, 2012. https://doi.org/10.1007/s11628-011-0123-9

BRIDGSTOCK, R.; LETTICE, F.; ÖZBILGIN, M. F.; TATLI, A. Diversity management for innovation in social enterprises in the UK. Entrepreneurship and Regional $\begin{array}{llllll}\text { Development, } & \text { v. } 22, \quad \text { n. } \quad 6, \quad \text { p. } & 557-574,\end{array}$ https://doi.org/10.1080/08985626.2010.488404

CAJAIBA-SANTANA, G. Social innovation: moving the field forward: a conceptual framework. Technological Forecasting and Social Change, v. 82, p. 42-51, 2014. https://doi.org/10.1016/j.techfore.2013.05.008

CHAMBON, J. L.; DAVID, A.; DEVEVEY, J. M. Les innovations sociales. Paris: Presses Universitaires de France, 1982.

COENEN, F.; DÍAZ LÓPES, F. J. The greening of the chemical industry: past, present and challenges ahead. In: SANGHI, R.; SINGH, V. (Eds.). Green Chemistry for Environmental Remediation. Salem: John Wiley \& Sons, 2010. p. 35-78.

DAWSON, P.; DANIEL, L. Understanding social innovation: a provisional framework. International Journal of Technology Management, v. 51, n. 1, p. 9-21, 2010. https://doi.org/10.1504/IJTM.2010.033125

DOSI, G. Mudança técnica e transformação industrial. Campinas: Editora da Unicamp, 2006.

FOSTER, C.; HEEKS, R. Conceptualising inclusive innovation: Modifying systems of innovation frameworks to understand diffusion of new technology to low-income consumers. The European Journal of Development Research, v. 25, n. 3, p. 333-355, 2013. https://doi.org/10.1057/ejdr.2013.7

GUIA EXAME DE SUSTENTABILIDADE. São Paulo: Abril, 2014.

HOLMES, S.; SMART, P. Exploring open innovation practice in firm-nonprofit engagements: a corporate social responsibility perspective. R \& D Management, v. 39, n. 4, p. 394-409, 2009. 10.1111/j.1467-9310.2009.00569.x

JACOBSSON, S.; BERGEK, A. Innovation system analyses and sustainability transitions: contributions and suggestions for research. Environmental Innovation and Societal Transitions, v. 1, n. 1, p. 41-57, 2011. https://doi.org/10.1016/j.eist.2011.04.006

JORGENSON, D.; GOETTLE, R.; SING HOC, M.; WILCOXEN, P. Cap and trade climate policy and U.S. economic adjustments. Journal of Policy Modeling, v. 31, n. 3, p. 362381, 2009.

KANTER, R. M. From spare change to real change: the social sector as beta site for business innovation. Harvard Business Review, v. 77, n. 3, p. 122-132, 1999.

KEMP, R.; PEARSON, P. (Eds.). Final Report MEI Project about Measuring EcoInnovation. Maastricht: University of Maastricht, 2007. 
MACLEAN, M.; HARVEY, C.; GORDON, J. Social innovation, social entrepreneurship and the practice of contemporary entrepreneurial philanthropy. International Small $\begin{array}{llllllll}\text { Business Journal, } & \text { v. 31, n. 7, p. 747-763, }\end{array}$ https://doi.org/10.1177\%2F0266242612443376

MARKARD, J.; RAVEN, R.; TRUFFER, B. Sustainability transitions: an emerging field of research and its prospects. Research Policy, v. 41, n. 6, p. 955-967, 2012. https://doi.org/10.1016/j.respol.2012.02.013

MAURER, A. M.; SILVA, T. N. Dimensões analíticas para identificação de inovações sociais: evidências de empreendimentos coletivos. Brazilian Business Review, v. 11, n. 6, p. 127-150, 2014.

MULGAN, G. The process of social innovation. Innovations: Technology, Governance, Globalization, v. 1, n. 2, p. 145-162, 2006.

ORGANIZATION FOR ECONOMIC CO-OPERATION AND DEVELOPMENT - OECD. Manual de Oslo: diretrizes para coleta e interpretação de dados sobre inovação. 3. ed. Rio de Janeiro: FINEP, 2005.

RENNINGS, K. Redefining innovation - eco-innovation research and the contribution from ecological economics. Ecological Economics, v. 32, n. 2, p. 319-332, 2000.

SCHUMPETER, A. Teoria do desenvolvimento econômico: uma investigação sobre lucros, capital, crédito, juro e ciclo econômico. São Paulo: Nova Cultural, 1997. https://doi.org/10.1016/S0921-8009(99)00112-3

VAN DEN BERGH J. C. J. M.; TRUFFER, B.; KALLIS, G. Environmental innovation and societal transitions: introduction and overview. Environmental Innovation and Societal Transitions, v. 1, n. 1, p. 1-23, 2011. https://doi.org/10.1016/j.eist.2011.04.010 
Appendix A. Reports highlighted by the companies.

\begin{tabular}{lll}
\hline Sector & Fompany & Efficiency, reducing greenhouse gas emissions (GGEs), logistics - invested in logistics, \\
& Bunge & $\begin{array}{l}\text { with a } 20 \% \text { reduction in the route of grain and a 20\% reduction in the emission of carbon } \\
\text { originating from transport - reduction of } 100,000 \text { truck trips. Restrictions on suppliers that }\end{array}$
\end{tabular}
violate environmental and labor standards.

$\begin{array}{ll}\text { Agribusiness } & \begin{array}{l}\text { Environmental and social certification - invested in international certification to avoid } \\ \text { the risk of having products barred abroad for social or environmental issues. }\end{array} \\ \begin{array}{l}\text { Odebrecht } \\ \text { Agro- } \\ \text { industrial }\end{array} & \begin{array}{l}\text { Supported communities - invested in the training of bricklayers and bakers, to meet labor } \\ \text { shortages in the cities where they are installing their industries. }\end{array}\end{array}$

Agroshortages in the cities where they are installing their industries.

Efficiency, energy, reduction in GGEs, reuse - invested in productive efficiency.

Volvo Decrease of $63 \%$ in the energy needed to manufacture a vehicle and a $50 \%$ reduction in GGEs. Currently, $90 \%$ of the waste of raw materials - iron and plastic - is processed at

$\begin{array}{ll}\text { Auto Industry } & \text { GGEs. Currently, } 90 \% \text { of the waste of raw materials - iron and plastic - is processed at } \\ \text { the factory. } & \text { Efficiency, power, water - searched for more-efficient uses of resources, causing a } 15 \%\end{array}$

Efficiency, power, water - searched for more-efficient uses of resources, causing
reduction in water consumption and a $28 \%$ reduction in electricity consumption.

\begin{tabular}{lll}
\hline Tetra Pak & $\begin{array}{l}\text { Using sustainable resources - the use of renewable materials in 2014 went from 75\% to } \\
82 \% \text {. Expanded the use of recycled materials in the production process. }\end{array}$ \\
Energy efficiency - became one of the first companies in the country to apply \\
Enternational standards of energy management: ISO50001. A reduction of $13 \%$ of \\
electricity consumption in the assembly lines.
\end{tabular}

Unilever Supplier certification - working with its suppliers to achieve the target of $100 \%$ of agricultural raw materials having certification of origin by the end of the decade.

Reduction of materials in packaging, collectors - has programs to reduce raw materials

Brasil Kirin in packaging. In 2013, it saved 4,000 tons of plastic resin. Works with partnership collectors for collecting discarded packaging material.

Coca-Cola Development of poor communities - invested in the development of small-scale suppliers of extractive communities in the Amazon.

Consumer Goods

Energy efficiency - invested in the efficient use of natural resources. In the reform of its
Grupo first plant, it reduced the consumption of electricity by $20 \%$, and its new plant has been

$\begin{array}{ll}\text { Boticário } & \text { first plant, it reduced the consumption of electricity by } 20 \%, \\ \text { designed with attention to the better use of natural resources. }\end{array}$

Kimberly- $\quad$ Reduction in water consumption - invested in reducing water consumption in the paper Clark manufacturing process. In 2013, it needed 5,000 liters of water to produce 1 ton of paper.

Efficiency, mitigation, networking - The company proposes a business management that makes possible a positive impact on the environment.

and electricity.
Efficiency, water, collectors - specializes in developing environmental solutions with

Promon positive social impacts. Implemented a recycling system that benefits recycling cooperatives and a closed-loop water system that eliminates the need for the collection and disposal of water.

Consulting and

IT Management Ecofrotas Carbon credits - developed a methodology that allows the sale of carbon credits with the adoption of ethanol in the car fleet.

EY Sustainable logistics chain - created a methodology for building sustainable supply chains and applied its knowledge in planning the 2016 Olympics in Rio de Janeiro. years.

Embraco $\quad$ Reuse - invested in its business based on the reuse of material that would be discarded. Reused $96 \%$ of solid waste from industrial processes.

\begin{tabular}{|c|c|c|c|}
\hline \multirow{5}{*}{ Electronics } & Philips & $\begin{array}{l}\text { Efficiency of products - invested in the development of products with higher energy } \\
\text { efficiency and lower costs. One example is LED lamps - the price dropped } 70 \% \text { in two } \\
\text { years. }\end{array}$ & EI \\
\hline & Embraco & $\begin{array}{l}\text { Reuse }- \text { invested in its business based on the reuse of material that would be discarded. } \\
\text { Reused } 96 \% \text { of solid waste from industrial processes. }\end{array}$ & EI \\
\hline & HP & $\begin{array}{l}\text { Efficient products and processes, reuse - implemented the circular economy concept } \\
\text { and developed partnerships with suppliers to reduce resource consumption and increase } \\
\text { the efficiency of products. Its products were also made more energy efficient. }\end{array}$ & EI \\
\hline & $\begin{array}{l}\text { Schneider } \\
\text { Electric }\end{array}$ & $\begin{array}{l}\text { Supplier development, GGE reduction, supporting the community - developed the } \\
\text { sustainability of its suppliers. Reduction in GGEs. Training 15,000 people from } \\
\text { disadvantaged communities through electrician courses. }\end{array}$ & $\begin{array}{l}\text { EI } \\
\text { SI }\end{array}$ \\
\hline & Whirlpool & $\begin{array}{l}\text { Water saving - saved water in appliance manufacturing and encouraged consumers to do } \\
\text { the same by purchasing its washing machines. }\end{array}$ & EI \\
\hline
\end{tabular}




\begin{tabular}{|c|c|c|c|}
\hline Continued... & & & \\
\hline \multirow{8}{*}{ Energy } & AES Brasil & $\begin{array}{l}\text { Sustainable energy - diversified its sources of power generation. Installed solar plants with } \\
\text { hydroelectric plants to take advantage of the structure. It aimed to double the capacity of its } \\
\text { power generation via sustainable energy by } 2016 \text {. }\end{array}$ & EI \\
\hline & Ampla & $\begin{array}{l}\text { Electricity consumption hours - by } 2015 \text {, it aimed for customers in the city of Buzios to be } \\
\text { able to choose appropriate tariffs based on their spending habits. }\end{array}$ & EI \\
\hline & Coele & $\begin{array}{l}\text { Consumer awareness, supporting communities - implemented programs offering discounts } \\
\text { in exchange for recyclable waste and the replacement of inefficient electric appliances. } \\
\text { Encouraged customers to use less electricity. }\end{array}$ & EI \\
\hline & $\begin{array}{l}\text { CPFL } \\
\text { Energia }\end{array}$ & $\begin{array}{l}\text { Alternative energy - expanded investments in renewable sources of electricity and imposed } \\
\text { sustainability goals for its executives. }\end{array}$ & EI \\
\hline & EPD & $\begin{array}{l}\text { Energy, supporting communities - invested } 430 \text { million reais ( } 162 \text { million dollars as of } \\
\text { December } 31,2014) \text { in social and environmental programs in communities affected by its new } \\
\text { hydroelectric plants. }\end{array}$ & $\begin{array}{l}\text { EI } \\
\text { SI }\end{array}$ \\
\hline & Elektro & $\begin{array}{l}\text { Local suppliers - promoted the economy in its concession areas. In } 2014,75 \% \text { of business } \\
\text { was done with local partners. }\end{array}$ & SI \\
\hline & $\begin{array}{l}\text { Itaipu } \\
\text { Binacional }\end{array}$ & $\begin{array}{l}\text { Use of electricity - invested in sustainable forms of electricity use. Supported the development } \\
\text { of electric cars. }\end{array}$ & EI \\
\hline & Light & $\begin{array}{l}\text { Reduction in energy theft - invested in the fight against energy theft, which drains } 16 \% \text { of the } \\
\text { energy distributed by the company in Rio de Janeiro. }\end{array}$ & EI \\
\hline Hotels & $\begin{array}{l}\text { Grupo Rio } \\
\text { Quente }\end{array}$ & $\begin{array}{l}\text { Environmental education - educational programs are the foundation of the sustainability } \\
\text { policy of Rio Quente Group. Sourced alternative energy - heating shower water was done by } \\
\text { solar panels. }\end{array}$ & EI \\
\hline \multirow{2}{*}{ Infrastructure } & CCR & $\begin{array}{l}\text { Education for transit - has a program that contributes to training future drivers and } \\
\text { decreasing accident rates on the roads. }\end{array}$ & SI \\
\hline & Ecoro-dovias & $\begin{array}{l}\text { Energy efficiency - its road modernization includes energy efficiency with the introduction of } \\
\text { LED lamps and solar panels. }\end{array}$ & EI \\
\hline \multirow{4}{*}{$\begin{array}{l}\text { Financial } \\
\text { Institutions }\end{array}$} & $\begin{array}{l}\text { Itaú } \\
\text { Unibanco }\end{array}$ & $\begin{array}{l}\text { Financial education - offered financial education for internal employees and business clients } \\
\text { in order to reduce default rates. }\end{array}$ & SI \\
\hline & Bradesco & $\begin{array}{l}\text { Investment in technology - invested in digital channels to keep customers away from the } \\
\text { rows of bank tellers. The cost of digital transactions is } 5 \% \text { of that in banks. }\end{array}$ & \\
\hline & $\begin{array}{l}\text { Grupo BB } \\
\text { and Mapfre }\end{array}$ & $\begin{array}{l}\text { Risk assessment in contracts, reduction of resources - included sustainability issues in risk } \\
\text { assessments. It simplified the terms of the contracts, reducing paper usage by } 88 \% \text {. }\end{array}$ & EI \\
\hline & HSBC & $\begin{array}{l}\text { Fighting corruption - improved its internal controls and trained employees to prevent bribery } \\
\text { cases. }\end{array}$ & SI \\
\hline \multirow{2}{*}{$\begin{array}{l}\text { Construction } \\
\text { Materials }\end{array}$} & Masisa & $\begin{array}{l}\text { Integration of suppliers, professional training - achieved integration of the supply chain by } \\
\text { establishing a focus on sustainability. It operated in the training of professionals in the area and } \\
\text { the growth of the furniture sector. }\end{array}$ & $\begin{array}{l}\text { EI } \\
\text { SI }\end{array}$ \\
\hline & Duratex & $\begin{array}{l}\text { Waste reduction - aimed to reduce industrial waste sent to landfill. In 2013, it recycled 33\% } \\
\text { of its waste. }\end{array}$ & EI \\
\hline \multirow{7}{*}{$\begin{array}{l}\text { Mining and } \\
\text { Steel Mills }\end{array}$} & $\begin{array}{l}\text { Arcelor- } \\
\text { mittal }\end{array}$ & $\begin{array}{l}\text { Energy efficiency, water consumption, reduction of GGEs - initiated a project to take } \\
\text { advantage of the gases from the burning charcoal used in the production process to generate } \\
\text { electricity. Achieved GGE reduction. Reused and treated water. }\end{array}$ & EI \\
\hline & Alcoa & $\begin{array}{l}\text { Forest recovery - invested in a mined area rehabilitation technique in Pará and created an } \\
\text { alternative income for the community. }\end{array}$ & $\begin{array}{l}\text { EI } \\
\text { SI }\end{array}$ \\
\hline & $\begin{array}{l}\text { AngloGold } \\
\text { Ashanti }\end{array}$ & $\begin{array}{l}\text { Water saving - its wastewater treatment facility in underground mining helped to save water, } \\
\text { achieving a } 7 \% \text { rate of water reuse and a } 58 \% \text { reduction in the volume of water pumped. }\end{array}$ & \\
\hline & Aperam & $\begin{array}{l}\text { Waste reduction, efficiency - in six years, the steel mill Aperam halved the generation of } \\
\text { waste in the manufacture of steel. The goal was to clear the remains of the production process. }\end{array}$ & \\
\hline & Vale & $\begin{array}{l}\text { Efficiency, reducing consumption of natural resources - aimed to extract iron ore while } \\
\text { having a minimal impact on the environment. In the new plant, there was a } 90 \% \text { reduction in } \\
\text { the volume of water used. Ore transportation was done by electric mats, not by } 300 \text { trucks. }\end{array}$ & \\
\hline & $\begin{array}{l}\text { Voto-rantim } \\
\text { Metais }\end{array}$ & $\begin{array}{l}\text { Efficiency, waste reduction, supporting the community, public managers - invested in } \\
\text { recycling electric arc furnace dust, the main waste generated in its plants. The goal is zero } \\
\text { waste from productive activity by } 2020 \text {. The Forest Ecos program focuses on developing } \\
\text { public awareness and training entrepreneurs and managers. }\end{array}$ & \\
\hline & Yamana & $\begin{array}{l}\text { Efficiency, reduced energy consumption - the company's strategy was to streamline costs, } \\
\text { seek efficiency and reduce electric and diesel power consumption. }\end{array}$ & I \\
\hline
\end{tabular}

Continue... 


\begin{tabular}{|c|c|c|c|}
\hline \multicolumn{4}{|l|}{ Continued... } \\
\hline Paper and Cellulose & Klabin & $\begin{array}{l}\text { Efficiency, waste reduction, supporting the surrounding community - invested in } \\
\text { biotechnology in the genetic improvement of eucalyptus in order to reduce the area } \\
\text { planted. Reduced solid waste going to landfill. It has social actions aimed at improving } \\
\text { the lives of neighboring communities. } \\
\text { Environmental certification - invested in FSC (Forest Stewardship Council) } \\
\text { certification of good practices in forest management for small providers acting in the } \\
\text { form of associations. }\end{array}$ & $\begin{array}{l}\text { EI } \\
\text { SI }\end{array}$ \\
\hline \multirow{5}{*}{ Chemistry } & Beraca & $\begin{array}{l}\text { Social project - developed a project to support low-income communities in Piauí } \\
\text { through access to clean water and education. }\end{array}$ & SI \\
\hline & Basf & $\begin{array}{l}\text { Efficiency, reducing consumption - performed a review of the processes of its unit in } \\
\text { São Bernardo do Campo to improve the consumption of water and electricity and to } \\
\text { reduce environmental impacts, waste generation and GGEs. }\end{array}$ & EI \\
\hline & Braskem & $\begin{array}{l}\text { Product innovation - invested } 200 \text { million reais ( } 75 \text { million dollars as of December } 31 \text {, } \\
2014 \text { ) in the year to drive innovation in green products. Developed raw materials } \\
\text { derived from sugar cane to replace oil. }\end{array}$ & EI \\
\hline & Dow Brasil & $\begin{array}{l}\text { Product innovation - developed a filter system that promises to reduce water treatment } \\
\text { costs by } 40 \% \text {. The technology began to be used on the São Paulo coast. }\end{array}$ & EI \\
\hline & $\begin{array}{l}\text { White } \\
\text { Martins }\end{array}$ & $\begin{array}{l}\text { Product innovation, efficiency - developed products and services to increase the } \\
\text { efficiency of its customers. It has also internally acted to increase its efficiency. }\end{array}$ & EI \\
\hline \multirow{4}{*}{ Health Services } & Sabin & Female work - supported female-dominated labor with constant training. & SI \\
\hline & Fleury Group & $\begin{array}{l}\text { Employee training - encouraged employees to give suggestions to improve business } \\
\text { processes. In 2013, the program generated savings of } 4 \text { million reais ( } 1.5 \text { million dollars } \\
\text { as of December } 31,2014) \text {. }\end{array}$ & SI \\
\hline & $\begin{array}{l}\text { Albert } \\
\text { Einstein } \\
\text { Hospital }\end{array}$ & $\begin{array}{l}\text { Supporting needy communities - the hospital provided care to more than } 10,000 \\
\text { children in the second largest slum in São Paulo. }\end{array}$ & SI \\
\hline & $\begin{array}{l}\text { Sírio-Libanês } \\
\text { Hospital }\end{array}$ & $\begin{array}{l}\text { Reducing the impacts of activities - adopted an international agenda to reduce the } \\
\text { impact of its activities in ten themes, including sustainable construction technologies, } \\
\text { green hospitals and a health-based international network. }\end{array}$ & EI \\
\hline \multirow[t]{2}{*}{ Telecommunications } & $\begin{array}{l}\text { Algar } \\
\text { Telecom }\end{array}$ & $\begin{array}{l}\text { Environmental design, supplier development - developed a recycling project that } \\
\text { combines environmental, educational and social objectives. Collected banners and } \\
\text { transformed them into school materials, which were then donated to the public. It } \\
\text { ensured its suppliers were committed to sustainability. }\end{array}$ & $\begin{array}{l}\text { EI } \\
\text { SI }\end{array}$ \\
\hline & $\begin{array}{l}\text { Telefônica } \\
\text { Vivo }\end{array}$ & $\begin{array}{l}\text { Digital inclusion - provided Internet access to rural schools. In } 2014 \text {, its digital } \\
\text { inclusion program benefited } 4,000 \text { rural schools. The goal was to connect } 22,000 \text { rural } \\
\text { schools. }\end{array}$ & SI \\
\hline $\begin{array}{l}\text { Transportation and } \\
\text { Logistics }\end{array}$ & $\begin{array}{l}\text { Libra } \\
\text { Group }\end{array}$ & $\begin{array}{l}\text { GGE reduction, replacing diesel with electricity - invested in electrical equipment for } \\
\text { the transport of loads to reduce the GGEs in port operations. }\end{array}$ & EI \\
\hline SMEs & Zanzini & $\begin{array}{l}\text { Relationships with society, recycling - invested in relationships with social actors and } \\
\text { the use of recycled materials. }\end{array}$ & $\begin{array}{l}\text { EI } \\
\text { SI }\end{array}$ \\
\hline
\end{tabular}

Source: Authors based on Guia Exame de Sustentabilidade (2014).

Notes: Class* = classification: EI or SI.

SME: Small and medium enterprises. 